\title{
ANALISIS DAMPAK PENINGKATAN ALOKASI ANGGARAN PADA SEKTOR INDUSTRI MAKANAN DAN MINUMAN TERHADAP PEMBANGUNAN EKONOMI JAWA TENGAH
}

\author{
Analysis of the Impact of the Budget Allocation Improvement in the Food and Beverages \\ Industrial Sector to Economic Development of Central Java
}

\author{
Kurniawan Ari Setyanto1, Harianto'2, Sugeng Budiharsono ${ }^{3}$
}

\author{
1Staf Kantor Pelayanan Perbendaharaan Negara Jakarta IV, DKI Jakarta 10310. E-mail: ari.bgt@gmail.com \\ 2 Staf Pengajar Departemen Agribisnis. Fakultas Ekonomi dan Manajemen. IPB. Email: harianto_ipb@yahoo.com \\ 3 Staff Pengajar Sekolah Pascasarjana, IPB. Email: sbudiharsono@gmail.com
}

\begin{abstract}
The movement of the development paradigm causes development direction not only focuses on growth but also as an effort in reducing poverty and unemployment level and also in improving the quality of human life. The priorities of the economic development should be directed to the leading sector development which has strong relevance to other sectors, so that the sector development will provide a great multiplier effect on the economy. Food and beverages industry is one of the leading sector that contributes greatly to the GRDP of Central Java. The purposes of this research were to analyze the role of the food and beverages industrial sector for the economy of Central Java by using input and output analysis, and to analyze the impact of the increasing budget allocation through government consumption in this sector by using a system dynamic analysis. The results of this research showed that the food and beverages industrial sector had a forward linkage coefficient of 2.42 and backward linkage coefficient of 2.18, and also forward dan backward linkage indexes above 1 which meant that the sector was the key sector in the economy of Central Java because it had strong linkage with other sectors. Simulations on increasing of the allocation of government consumption in that sector had a positive impact on the increase of GRDP and IPM and in reducing poverty in Central Java, but the increase in budget allocation actually causes open unemployment rate in Central Java to increase.
\end{abstract}

Keywords: budget allocation, government consumption, GRDP, poverty, unemployment,

\begin{abstract}
ABSTRAK
Pergeseran paradigma pembangunan menyebabkan arah pembangunan tidak lagi hanya berfokus pada pertumbuhan, tetapi juga sebagai sebuah usaha dalam mengurangi tingkat kemiskinan dan pengangguran serta dalam meningkatkan kualitas hidup manusia. Prioritas pembangunan ekonomi hendaknya diarahkan pada pengembangan sector unggulan yang mempunyai keterkaitan yang besar kepada sektor lainnya, sehingga pengembangan sektor tersebut akan memberikan multiplier effect yang besar terhadap perekonomian. Industri makanan dan minuman merupakan salah satu sektor unggulan yang memberikan kontribusi besar terhadap PDRB Jawa Tengah, sehingga pengembangan sektor tersebut diharapkan akan dapat meningkatkan pembangunan ekonomi Jawa Tengah. Tujuan dari penelitian ini adalah untuk menganalisis peran sektor industri makanan dan minuman bagi perekonomian Jawa Tengah dengan menggunakan analisis input output, serta menganalisis dampak peningkatan alokasi anggaran melalui konsumsi pemerintah pada sektor tersebut dengan menggunakan analisis sistem dinamik. Hasil penelitian menunjukkan bahwa sektor industri makanan dan minuman memiliki koefisien forward linkage sebesar 2.42 dan koefisien backward linkage sebesar 2.18, serta indeks forward dan backward linkage diatas 1 yang berarti bahwa sektor tersebut merupakan sektor kunci dalam perekonomian Jawa Tengah karena memiliki keterkaitan yang kuat dengan sektor lainnya. Simulasi terhadap peningkatan alokasi konsumsi pemerintah pada sektor tersebut memberikan dampak yang positif terhadap peningkatan PDRB dan IPM serta dalam menurunkan angka kemiskinan di Jawa Tengah, namun peningkatan tersebut menyebabkan tingkat pengangguran terbuka bertambah.
\end{abstract}

Keywords: alokasi anggaran, konsumsi pemerintah, PDRB, kemiskinan, pengangguran

\section{PENDAHULUAN}

Pembangunan ekonomi merupakan serangkaian usaha dalam suatu perekonomian untuk mengembangkan kegiatan ekonominya yang berdampak pada terjadinya perubahan dalam berbagai 
aspek kegiatan ekonomi (Sukirno 2006). Dalam pandangan tradisional, indikator keberhasilan pembangunan ekonomi identik dengan pertumbuhan ekonomi yang tinggi yang tercermin dari tingkat pendapatan perkapita masyarakat. Namun, tingkat pertumbuhan ekonomi yang tinggi tersebut ternyata tidak dapat menyelesaikan masalah-masalah yang timbul seperti masalah pengangguran, kemiskinan, ketimpangan distribusi pendapatan hingga masalah ketidakseimbangan struktural (Kuncoro 1997). Pergeseran paradigma pembangunan menyebabkan arah pembangunan tidak lagi hanya terfokus pada pertumbuhan ekonomi, namun juga dalam hal mengurangi tingkat kemiskinan dan pengangguran serta dalam hal meningkatkan kualitas hidup manusia.

Perekonomian di Indonesia masih terkonsentrasi di pulau Jawa. Menurut Badan Pusat Statistik (2016a), kontribusi pulau Jawa dalam pembentukan Produk Domestik Bruto (PDB) nasional tahun 2015 lebih dari 58 persen. Namun dari kontribusi pulau Jawa tersebut, kontribusi Produk Domestik Regional Bruto (PDRB) Provinsi Jawa Tengah tergolong kecil dibanding Provinsi DKI Jakarta, Jawa Timur dan Jawa Barat. Berdasarkan data BPS (2016a), PDRB Jawa Tengah berdasarkan harga konstan pada tahun 2015 berperan sebesar 8.93 persen terhadap PDB nasional, jauh dari Provinsi DKI Jakarta yang sebesar 16.1 persen, Jawa Timur 14.74 persen dan Jawa Barat 13.37 persen. Sedangkan rata-rata pertumbuhan ekonomi antara tahun 2011 sampai 2015 sebesar 5.29 persen, dibawah rata-rata pertumbuhan nasional yang sebesar 5.51 persen.

PDRB erat kaitannya dengan tingkat pengangguran dan kemiskinan. PDRB merupakan representasi dari tingkat pendapatan masyarakat. PDRB yang rendah mengindikasikan tingkat pendapatan perkapita masyarakat yang rendah pula. Pendapatan masyarakat yang rendah menyebabkan seseorang memiliki kemampuan ekonomi yang rendah dalam memenuhi kebutuhan dasarnya. BPS
(2009) memandang kemiskinan sebagai ketidakmampuan dari sisi ekonomi untuk memenuhi kebutuhan dasar makanan dan bukan makanan. Selain itu, PDRB juga mencerminkan tingkat produksi barang/jasa di suatu wilayah. Semakin tinggi PDRB maka semakin tinggi pula barang/jasa yang diproduksi, sehingga memerlukan jumlah tenaga kerja yang lebih besar untuk memproduksi barang/jasa tersebut. PDRB yang rendah akan menyebakan penyerapan tenaga kerja yang rendah, sehingga pengangguran menjadi meningkat.

Indikator tingkat kemiskinan menunjukkan bahwa tingkat kemiskinan di Jawa Tengah tergolong tinggi. Tingkat kemiskinan Jawa Tengah sampai dengan bulan Maret 2016 sebesar 13.27 persen, diatas rata-rata nasional yang sebesar 10.86 persen (BPS 2016b). Sedangkan Indeks Pembangunan Masyarakat (IPM) yang merupakan cermin dari pembangunan kualitas hidup manusia menunjukkan bahwa pada tahun 2015, IPM Jawa Tengah masuk kategori sedang yaitu berada pada indeks sebesar 69.49, sedikit dibawah rata-rata nasional 69.55 (BPS 2016c). Disisi lain tingkat pengangguran terbuka di Jawa Tengah sampai dengan tahun 2015 masih tinggi, yaitu sebesar 4.99 persen atau sejumlah 863.783 orang (BPS 2016d).

Rencana Pembangunan Jangka Menengah Daerah (RPJMD) Jawa Tengah tahun 2013-2018 menyatakan bahwa sektor unggulan yang paling banyak dan menyebar di wilayah Jawa Tengah didominasi oleh sektor pertanian dan sektor industri pengolahan (Pemprov. Jawa Tengah 2014). Namun, tranformasi struktur ekonomi di Jawa Tengah menyebabkan kontribusi sektor pertanian terhadap PDRB Jawa Tengah terus mengalami penurunan sejak tahun 1983 sampai dengan 2003 dimana kontribusi sektor pertanian yang semula sebesar 34.9 persen pada tahun 1983 turun menjadi hanya 18.6 persen pada tahun 2003. Disisi lain kontribusi sektor industri yang semula hanya berkontribusi sebesar 11.5 persen 
pada tahun 1983 naik menjadi 31.19 persen pada tahun 2003 (Sudarmono 2006).

Sampai dengan saat ini sektor pertanian masih tetap menjadi fokus pembangunan di Jawa Tengah mengingat ketahanan pangan merupakan salah satu faktor penentu stabilitas ekonomi sehingga upaya kecukupan pangan menjadi kerangka pembangunan yang mampu mendorong pembangunan sektor lainnya (Pemprov. Jawa Tengah 2014). Alternatif pembangunan sektor pertanian dapat dilakukan dengan melakukan keterpaduan antara sektor pertanian dengan sektor lain yang lebih unggul dalam penciptaan pertumbuhan ekonomi dan memiliki keterkaitan dengan sektor pertanian, yaitu sektor industri pengolahan (Jhingan 2007). Keterkaitan industri dengan sektor pertanian amat kuat apabila sektor industri mempunyai keterkaitan kebelakang yang tinggi (King dan Byerlee dalam Kuncoro 2007). Salah satu industri pengolahan yang mempunyai keterkaitan tinggi terhadap sektor pertanian yaitu agroindustri, dimana salah satunya adalah industri makanan dan minuman.

Berdasarkan data BPS (2016e), produksi industri makanan dan minuman terhadap total produksi sektor industri pengolahan Tahun 2015 tertinggi dibandingkan jenis industri lainnya yaitu sebesar 32.89 persen, dengan laju pertumbuhan tertinggi yaitu sebesar 9.45 persen. Kemajuan perkembangan industri makanan dan minuman tidak lepas dari perannya dalam menghasilkan produk yang merupakan kebutuhan pokok manusia. Oleh sebab itu, penyebaran industri makanan dan minuman merata hampir di semua wilayah Jawa Tengah. Berdasarkan data Dinas Perindustrian dan Perdagangan Provinsi Jawa Tengah (2014), jumlah industri makanan dan minuman di Jawa Tengah pada tahun 2014 sebanyak 8763 industri, yang merupakan jenis industri agro, kimia dan hasil hutan terbanyak di Jawa Tengah setelah industri mebel yang berjumlah 2256 industri dan industri rokok sebanyak 1840 industri.

Dalam teori permintaan agregrat, pengeluaran pemerintah mempunyai peran penting dalam mempengaruhi permintaan agregrat, yaitu sebagai komponen pengeluaran pemerintah melalui konsumsi pemerintah dan sebagai komponen investasi dalam pembentukan modal.

Nazara (1997) mengemukakan bahwa pengeluaran pemerintah merupakan variabel yang besarnya diatur sepenuhnya oleh pemerintah sendiri serta dapat mempengaruhi peningkatan faktor-faktor lainnya melalui kebijakannya. Dalam konteks inilah, maka permintaan akhir dapat menjadi salah satu alat kebijakan pemerintah. Dalam pencapaian tujuan pembangunan ekonomi, pemerintah dapat memilih instrumen ekonomi yang akan digunakan untuk mendorong permintaan akhir suatu sektor ekonomi, dan sekaligus melihat bagaimana dampak dari perubahan permintaan akhir tersebut bagi perkembangan sektor ekonomi lainnya.

Selama ini peran belanja pemerintah sebagai faktor pendorong pertumbuhan ekonomi relatif kecil karena selain kecilnya porsi belanja modal dibandingkan porsi belanja rutin, juga sebagai akibat dari metode penyerapan anggaran yang terlalu terkonsentrasi di akhir tahun anggaran. Disisi lain, ketidaktepatan dalam mengalokasikan anggaran menimbulkan inefisiensi anggaran, karena dampak yang diharapkan dari setiap belanja pemerintah tidak terlalu berdampak multiplier terhadap perekonomian daerah. Keberhasilan pembangunan menuntut ketersediaan sumber daya yang memadai.

Kondisi pembangunan suatu wilayah dengan keterbatasan sumber daya mengakibatkan harus difokuskannya pembangunan pada sektor-sektor yang memiliki keterkaitan kuat dengan sektor lainnya sehingga akan memberikan dampak pengganda (multiplier effect) besar terhadap sektor-sektor lainnya atau perekonomian secara keseluruhan. Atas dasar tersebut diatas, tujuan penelitian ini adalah menganalisis peran industri makanan dan minuman dalam perekonomian Jawa Tengah, serta 
menganalisis dampak peningkatan alokasi anggaran pada sektor industri makanan dan minuman terhadap pembangunan ekonomi Jawa Tengah.

\section{METODE PENELITIAN}

\section{Jenis dan Sumber Data}

Data yang digunakan dalam penelitian ini menggunakan data sekunder. Data sekunder bersumber dari : (1) Badan Pusat Statistik Provinsi Jawa Tengah; (2) Badan Pusat Statistik RI; (3) Dinas Perindustrian dan Perdagangan Provinsi Jawa Tengah.

\section{Metode Analisis Data}

\section{Analisis Input Output}

Analisis input output adalah suatu analisis atas perekonomian wilayah secara komprehensif karena melihat keterkaitan antar sektor ekonomi di wilayah tersebut secara keseluruhan (Tarigan 2005). Penelitian ini menggunakan tabel input output Jawa Tengah tahun 2013 yang kemudian dilakukan updating data menjadi tabel input output tahun 2015. Metode yang digunakan untuk melakukan updating data adalah dengan metode RAS. Dalam penenlitian ini, tabel input output
Jawa Tengah 2015 diagregrasi dari semula 88 sektor dengan matriks $88 \times 88$ menjadi 9 sektor dengan matriks 9x9. Output dari analisis input output adalah :

1. Forward dan backward linkage sektor-sektor ekonomi.

2. Koefisien multiplier output, NTB, upah/gaji dan tenaga kerja.

\section{Analisis Sistem Dinamik}

Sistem dinamik merupakan suatu metode sederhana yang menggunakan causal- loop dan stock flow untuk menjelaskan hubungan diantara sistem (Kusumo 2012). Causal loop merupakan gambaran hubungan antar variabel dalam suatu sistem yang menunjukkan suatu hubungan sebab akibat. Selain itu, causal loop juga digunakan untuk membatasi sistem yang akan dikaji (Muhammadi et al. 2001). Sistem dinamik digunakan untuk mengetahui dan menguji kebijakan yang diperlukan di masa mendatang (Prasodjo 2015). Analisis secara teknis dilakukan dengan membangun struktur (Stock Flow Diagram) untuk melakukan simulasi, dimana pengelompokan data dan input data dilakukan dalam struktur model (Firmansyah 2016). Diagram causal- loop penelitian ini seperti pada Gambar 1.

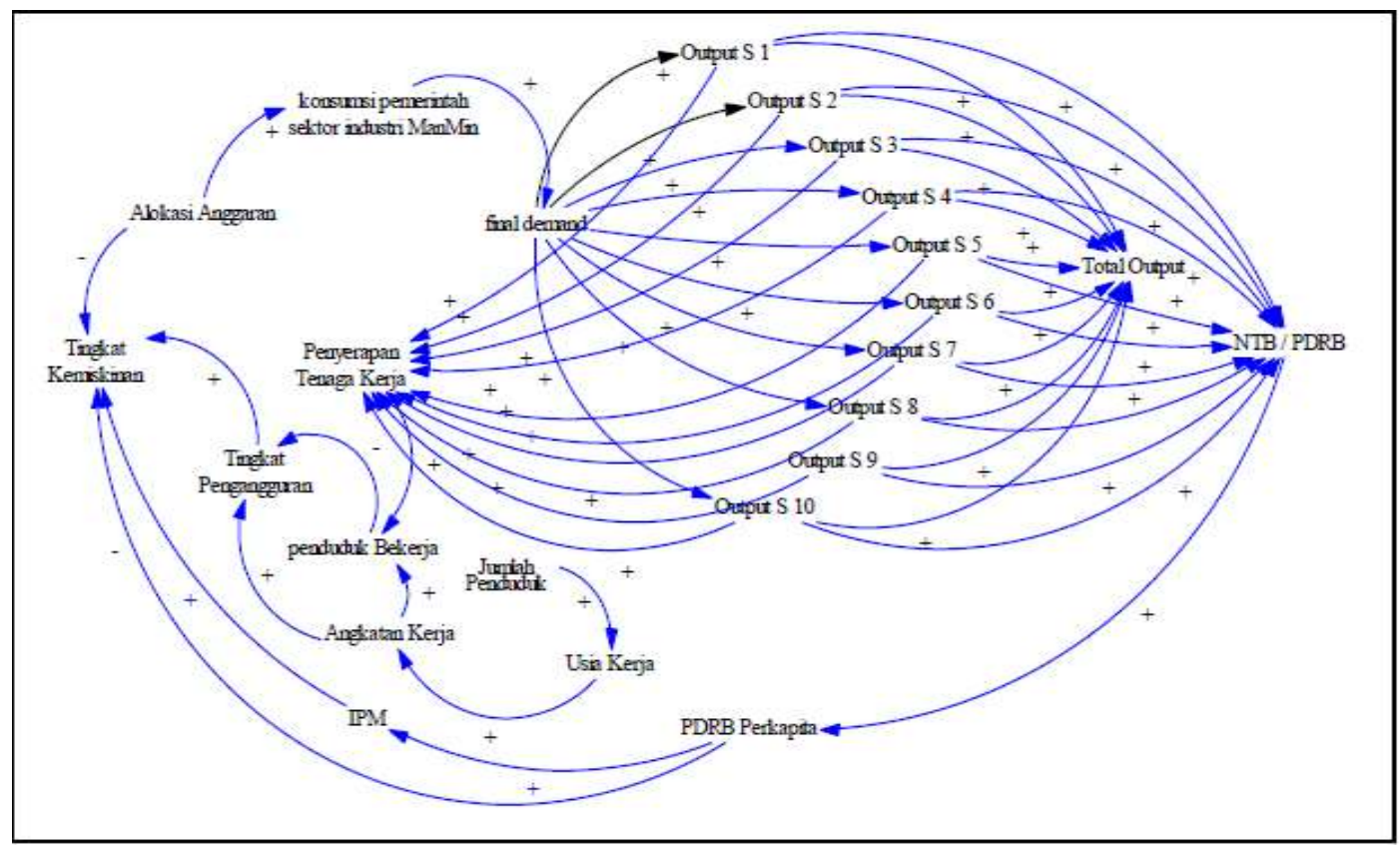

Gambar 1 Diagram Causal-Loop Pembangunan Ekonomi Jawa Tengah 
Batasan dalam model sistem dinamik ini adalah :

1. Peningkatan alokasi anggaran pemerintah daerah hanya pada variabel konsumsi pemerintah di sektor industri makanan dan minuman.

2. Nilai variabel ekonomi lainnya seperti konsumsi masyarakat, investasi, ekspor impor dan konsumsi pemerintah pada sektor lainnya diasumsikan sebesar laju pertumbuhan output/PDRB.

3. Faktor sumber daya manusia diabaikan, sehingga setiap peningkatan kesempatan kerja diasumsikan akan selalu diserap oleh angkatan kerja di Jawa Tengah

\section{HASIL DAN PEMBAHASAN}

\section{Peran Industri Makanan dan Minuman Dalam Perekonomian Jawa Tengah Koefisien Forward dan Backward Linkage}

Forward linkage atau daya penyebaran menunjukkan hubungan antar sektor dalam penjualan output dari suatu sektor ekonomi yang akan digunakan sebagai input bagi sektor ekonomi lainnya, sedangkan backward linkage atau derajat kepekaan menunjukkan hubungan antara sektor ekonomi dalam penyediaan bahan baku yang akan digunakan dalam proses produksi (BPS 2008). Pengembangan sektor ekonomi yang mempunyai forward dan backward linkage tinggi akan mempunyai dampak yang lebih besar terhadap pengembangan sektor ekonomi lainnya dibandingkan dengan apabila melakukan pengembangan sektor ekonomi yang memiliki forward dan backward linkage rendah.

Berdasarkan Tabel 1, sektor industri makanan dan minuman mempunyai koefisien backward linkage yang paling besar yaitu sebesar 2.18, sedangkan untuk koefisien forward linkage sebesar 2.87 atau berada pada posisi kedua setelah industri pengolahan lainnya. Indeks forward dan backward linkage sektor industri makanan dan minuman memiliki indeks masing-masing diatas 1 yang berarti bahwa daya penyebaran dan derajat kepekaan di atas rata-rata keseluruhan sektor. Tingginya indeks forward dan backward linkage industri makanan dan minuman menandakan bahwa sektor tersebut merupakan sektor kunci (key sector) yang harus dikembangkan kaitannya dalam meningkatkan pembangunan ekonomi di Jawa Tengah.

Tabel 1. Koefisien Forward Dan Backward Linkage Sektor Ekonomi Jawa Tengah

\begin{tabular}{|c|c|c|c|c|c|c|}
\hline \multirow{2}{*}{$\begin{array}{l}\text { Backward } \\
\text { SEKTOR }\end{array}$} & \multirow[b]{2}{*}{ Jumlah } & \multirow[b]{2}{*}{ Koef } & \multirow[b]{2}{*}{ Rank } & \multicolumn{3}{|c|}{ Forward } \\
\hline & & & & Jumlah & Koef & Rank \\
\hline Pertanian, Peternakan, Kehutanan dan Perikanan & 1.26 & 0.78 & 9 & 1.49 & 0.91 & 4 \\
\hline Pertambangan dan Penggalian & 1.27 & 0.78 & 8 & 1.10 & 0.67 & 9 \\
\hline Industri Makanan dan Minuman & 2.18 & 1.34 & 1 & 2.42 & 1.48 & 2 \\
\hline Industri Pendolahan Lainnya & 1.67 & 1.03 & 4 & 2.87 & 1.76 & 1 \\
\hline Konstruksi, Listrik, Gas dan Air Bersih & 1.94 & 1.19 & 2 & 1.11 & 0.68 & 8 \\
\hline Perdagangan,hotel dan Restauran & 1.58 & 0.97 & 6 & 1.38 & 0.85 & 7 \\
\hline Pengangkutan dan Komunikasi & 1.80 & 1.11 & 3 & 1.39 & 0.85 & 5 \\
\hline Lembaga Keuangan, Real Estate dan Jasa Keuangan & 1.35 & 0.83 & 7 & 1.39 & 0.85 & 6 \\
\hline Jasa-jasa dan Kegiatan Lainnya & 1.61 & 0.99 & 5 & 1.53 & 0.94 & 3 \\
\hline
\end{tabular}

Sumber : Data hasil analisis input output (2017)

Backward linkage sektor industri makanan dan minuman paling besar selain dengan sektor itu sendiri adalah dengan sektor pertanian, peternakan, kehutanan dan perikanan sebagai sektor penyedia input utama, sehingga peningkatan permintaan akhir di sektor industri makanan dan minuman akan berdampak besar terhadap pengembangan sektor pertanian, peternakan, kehutanan dan perikanan. 
Industri Pengolahan Makanan dan Minuman

Pertanian, Peternakan, Kehutanan dan... Industri Pendolahan Lainnya

Perdagangan,hotel dan Restauran

Pengangkutan dan Komunikasi

Jasa-jasa dan Kegiatan Lainnya

Lembaga Keuangan, Real Estate dan Jasa...

Konstruksi, Listrik, Gas dan Air Bersih

Pertambangan dan Penggalian

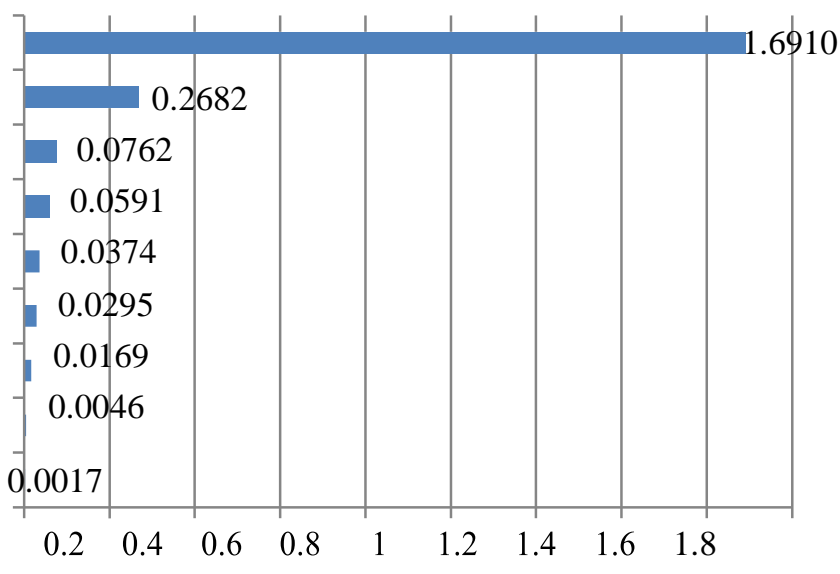

Sumber : Data hasil analisis input output (2017)

Gambar 2 Backward linkage sektor industri makanan dan minuman dengan sektor lainnya

\section{Angka Pengganda/Multiplier Effect}

Koefisien multiplier merupakan koefisien yang menyatakan kelipatan dampak langsung dan tidak langsung dari meningkatnya permintaan akhir suatu sektor ekonomi sebesar satu satuan terhadap aspek-aspek tertentu sektor ekonomi suatu wilayah (Rustiadi et al. 2011). Analisis ini dapat melihat seberapa besar perubahan-perubahan output, nilai tambah bruto (NTB), upah, dan penyerapan tenaga kerja sebagai akibat dari perubahan permintaan akhir suatu sektor. Dalam penelitian ini, angka multiplier menggunakan angka multiplier tipe I yang memposisikan permintaan akhir rumah tangga sebagai variabel exogenous dimana pengaruh konsumsi rumah tangga ikut mempengaruhi output sistem ekonomi secara keseluruhan.

Tabel 2. Koefisien Multiplier Sektor Ekonomi Jawa Tengah

\begin{tabular}{lllll}
\hline \multicolumn{1}{c}{ Sektor } & \multicolumn{4}{c}{ Koefisien Multiplier } \\
& & & & \\
& Output & NTB & Upah/Gaji & Tenaga Kerja \\
\hline Pertanian, Peternakan, Kehutanan dan Perikanan & 1.264 & 0.949 & 0.214 & 0.027 \\
Pertambangan dan Penggalian & 1.270 & 0.954 & 0.318 & 0.006 \\
Industri Makanan dan Minuman & 2.184 & 0.864 & 0.237 & 0.012 \\
Industri Lainnya & 1.671 & 0.746 & 0.225 & 0.009 \\
Konstruksi, Listrik, Gas dan Air Bersih & 1.943 & 0.803 & 0.274 & 0.011 \\
Perdagangan,hotel dan Restauran & 1.579 & 0.907 & 0.263 & 0.018 \\
Pengangkutan dan Komunikasi & 1.802 & 0.872 & 0.330 & 0.010 \\
Lembaga Keuangan, Real Estate dan Jasa Keuangan & 1.348 & 0.953 & 0.163 & 0.008 \\
Jasa-jasa dan Kegiatan Lainnya & 1.606 & 0.857 & 0.549 & 0.017 \\
\hline
\end{tabular}

Sumber : Data hasil analisis input output (2017)

Berdasarkan Tabel 2, sektor industri makanan dan minuman memiliki angka multiplier output terbesar dibandingkan sektor lainnya, yaitu sebesar 2.184. Namun untuk koefisien multiplier NTB hanya sebesar 0.864. Hal tersebut menunjukkan bahwa peningkatan NTB tidak sebanding dengan peningkatan output karena adanya faktor biaya produksi. Nilai koefisien multiplier upah/gaji sebesar 0.237 dan koefisien multiplier tenaga kerja sebesar 0.012. Koefisien mulitiplier tersebut menunjukkan bahwa apabila terjadi peningkatan permintaan akhir sebesar 1000 rupiah pada sektor industri makanan dan minuman, 
akan meningkatkan output sektor tersebut sebesar 2184 rupiah, NTB sebesar 864 rupiah dan upah/gaji sebesar 237 rupiah. Sedangkan untuk penyerapan tenaga kerja, peningkatan permintaan akhir sebesar 1 milyar rupiah akan meningkatkan penyerapan tenaga kerja sebanyak 12 orang.

\section{Pembangunan Model Sistem Dinamik}

Struktur model yang dibangun adalah untuk mengetahui bagaimana dampak peningkatan permintaan akhir pada sektor industri makanan dan minuman melalui peningkatan konsumsi pemerintah terhadap pembangunan ekonomi, meliputi PDRB, IPM, tingkat pengangguran dan tingkat kemiskinan di Jawa Tengah. Model dalam penelitian ini terbagi menjadi 4 submodel, yaitu submodel PDRB dan tenaga kerja, submodel pengangguran dan kemiskinan, submodel IPM dan submodel konsumsi pemerintah (Gambar 3).

\section{Validasi Model}

Validasi model merupakan suatu proses tahapan dalam analisis sistem dinamik yang bertujuan untuk menilai kesesuaian antara model yang dibangun dengan dunia nyata yang ditunjukkan dengan sejauh mana data simulasi dan pola simulasi dapat menirukan data statistik dan informasi aktul (fakta). Validasi model dilakukan dengan membandingkan antara besar dan sifat kesalahan (muhammadi et al. 2001), dengan menghitung Absolute Mean Error (AME) dan Absolute Variation Error (AVE). Model dapat dikatakan valid apabila nilai $\mathrm{AME} \leq 5$ persen dan $\mathrm{AVE} \leq 30$ persen.

Tabel 3. Validasi Model

\begin{tabular}{|c|c|c|}
\hline \multicolumn{3}{|c|}{ Data validasi PDRB konstan } \\
\hline Tahun & Nilai aktual & Nilai simulasi \\
\hline 2011 & 656268129.91 & 656207955.63 \\
\hline 2012 & 691343115.96 & 690374446.94 \\
\hline 2013 & 726655118.06 & 726509570.39 \\
\hline 2014 & 764959150.95 & 764737628.61 \\
\hline 2015 & 806775362.19 & 805191452.17 \\
\hline Mean & 729200175.41 & 725702767.51 \\
\hline $\mathrm{AME}$ & -0.4796 & \\
\hline Variance & 3513832865887980 & 3633750600307030 \\
\hline AVE & 3.4127 & \\
\hline \multicolumn{3}{|c|}{ Data validasi IPM } \\
\hline Tahun & Nilai aktual & Nilai simulasi \\
\hline 2011 & 66.64 & 66.63 \\
\hline 2012 & 67.21 & 67.01 \\
\hline 2013 & 68.02 & 67.84 \\
\hline 2014 & 68.78 & 68.39 \\
\hline 2015 & 69.49 & 69.36 \\
\hline Mean & 68.03 & 67.85 \\
\hline AME & -0.2675 & \\
\hline Variance & 1.3247 & 1.1914 \\
\hline AVE & -10.0584 & \\
\hline
\end{tabular}

Hasil uji (Tabel 3) menunjukkan bahwa nilai AME dan AVE hasil output model yang dibangun masih dibawah batas penyimpangan. Empat variabel yaitu

\begin{tabular}{ccr}
\hline \multicolumn{3}{c}{ Data validasi TPT } \\
\hline Tahun & Nilai aktual & Nilai simulasi \\
\hline 2011 & 7.07 & 6.98 \\
2012 & 5.61 & 5.42 \\
2013 & 6.01 & 5.95 \\
2014 & 5.68 & 5.96 \\
2015 & 4.99 & 5.31 \\
Mean & 5.87 & 5.93 \\
AME & 0.9418 & \\
Variance & 0.5844 & 0.4366 \\
AVE & -25.2931 & \\
\hline
\end{tabular}

\begin{tabular}{crr}
\hline \multicolumn{3}{c}{ Data validasi Angka Kemiskinan } \\
\hline Tahun & Nilai aktual & Nilai simulasi \\
\hline 2011 & 16.21 & 15.96 \\
2012 & 14.98 & 15.14 \\
2013 & 14.44 & 14.73 \\
2014 & 13.58 & 14.32 \\
2015 & 13.58 & 13.40 \\
Mean & 14.56 & 14.71 \\
AME & 1.0340 & \\
Variance & 1.2085 & 0.9061 \\
AVE & -25.0230 & \\
\hline
\end{tabular}

PDRB harga konstan, tingkat pengangguran terbuka, IPM dan angka kemiskinan memiliki nilai AME dibawah 5 persen, dan nilai AVE dibawah 30 persen. Dengan demikian disimpulkan 


$\begin{array}{lcc}\text { bahwa model yang } & \begin{array}{c}\text { dibangun valid } \\ \text { mensimulasikan }\end{array} & \begin{array}{l}\text { perubahan- perubahan yang terjadi terkait } \\ \text { pembangunan ekonomi di Jawa Tengah. }\end{array}\end{array}$

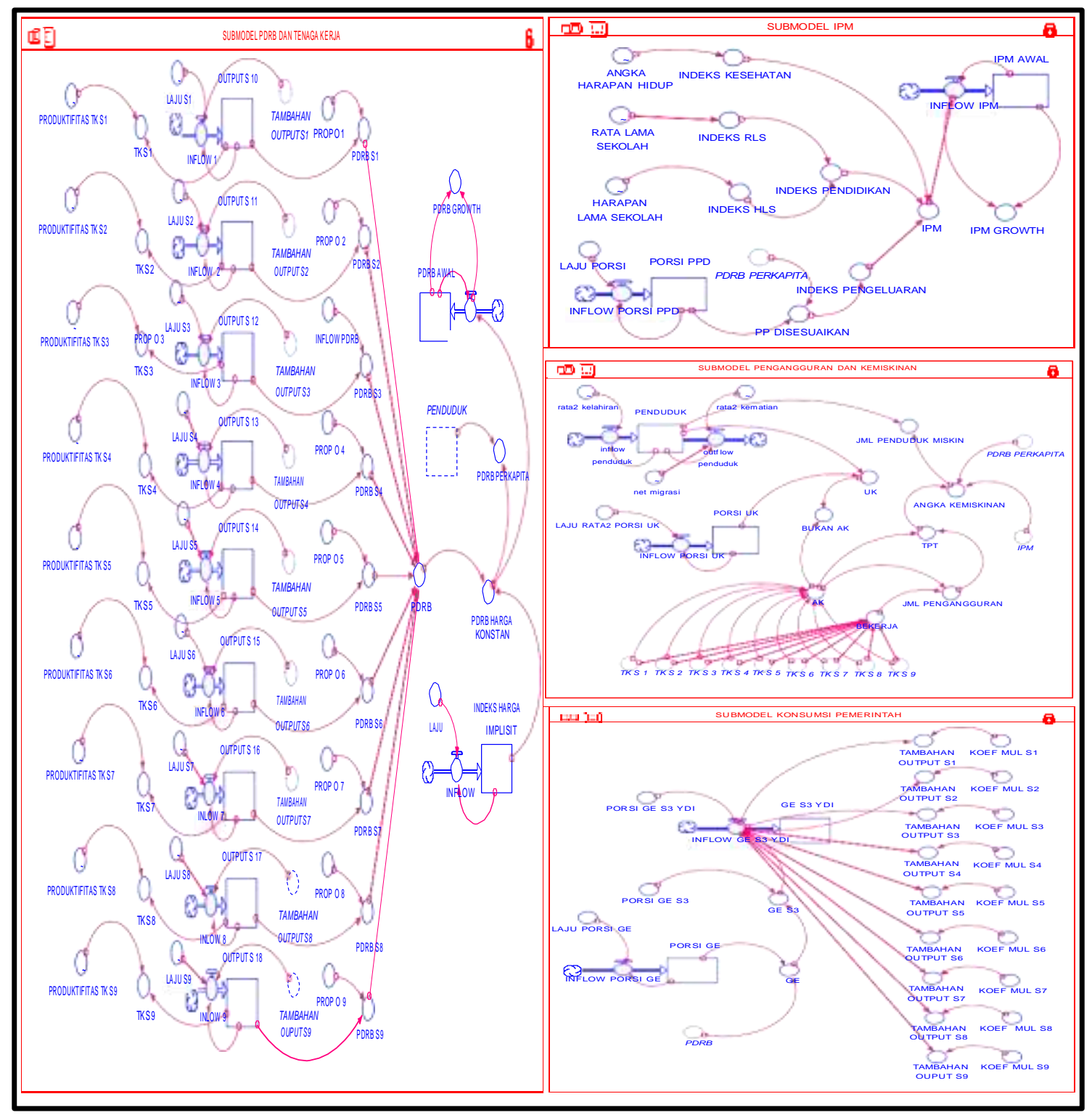

Gambar 3 Submodel sistem dinamik

\section{Hasil Simulasi Model (Existing)}

Perkembangan PDRB harga konstan (tahun dasar 2010) Jawa Tengah mengalami pertumbuhan yang positif sejak tahun 2011 sampai dengan 2030. Tercatat pertumbuhan PDRB Jawa Tengah setiap tahunnya hingga tahun 2030 terus mengalami peningkatan.
Berdasarkan hasil simulasi (Gambar 4), PDRB Jawa Tengah pada tahun 2030 mencapai sebesar 1804.67 triliun rupiah dan memiliki laju pertumbuhan sebesar persen. 


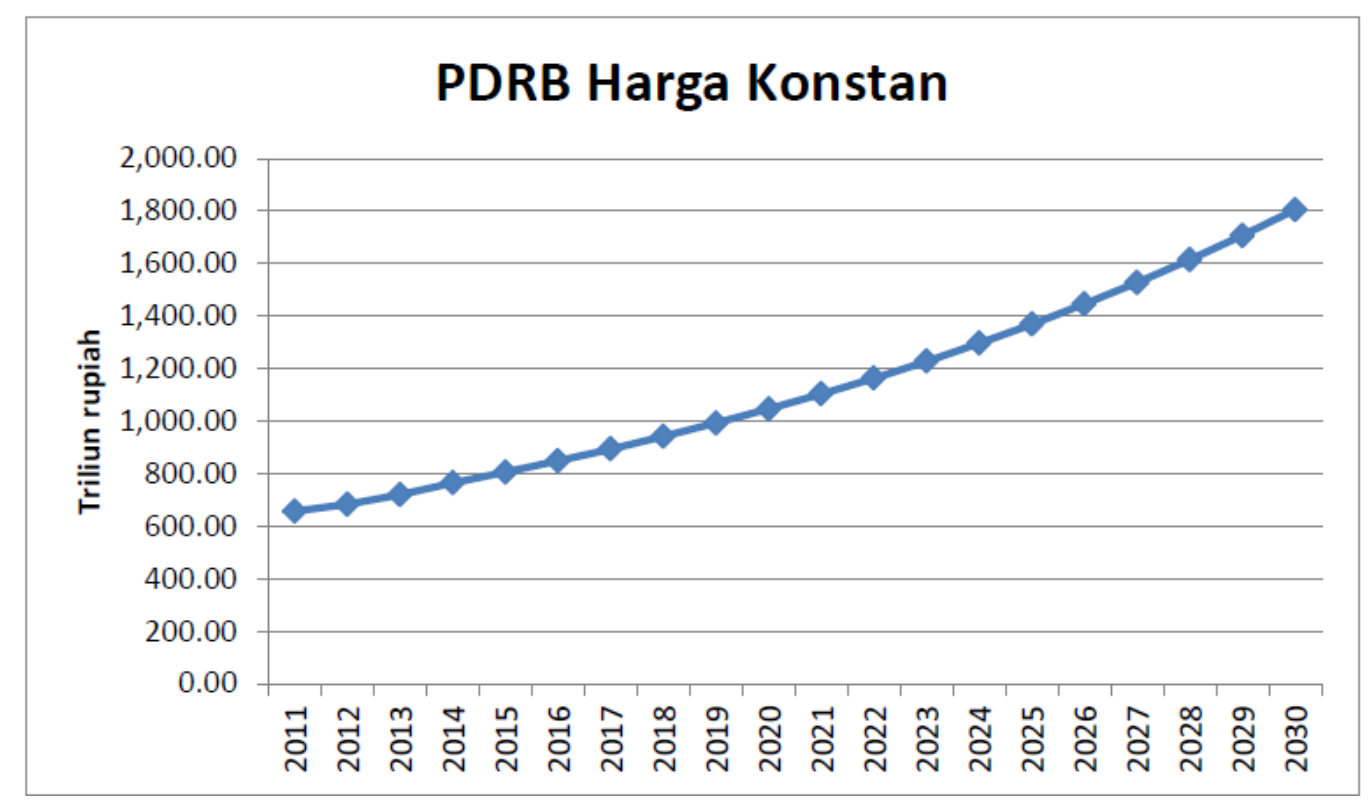

Gambar 4 Simulasi PDRB harga konstan Jawa Tengah tahun 2011-2030

Hasil simulasi terhadap IPM Jawa Tengah menunjukkan peningkatan yang positif. Peningkatan IPM Jawa Tengah mengalami peningkatan sebesar 19.05 persen sejak tahun 2011 hingga 2030. IPM Jawa
Tengah masuk pada kategori tinggi pada tahun 2017 dengan nilai indeks sebesar 70.38 dan pada tahun 2030, IPM Jawa Tengah sudah mencapai 79.32 (Gambar 5).

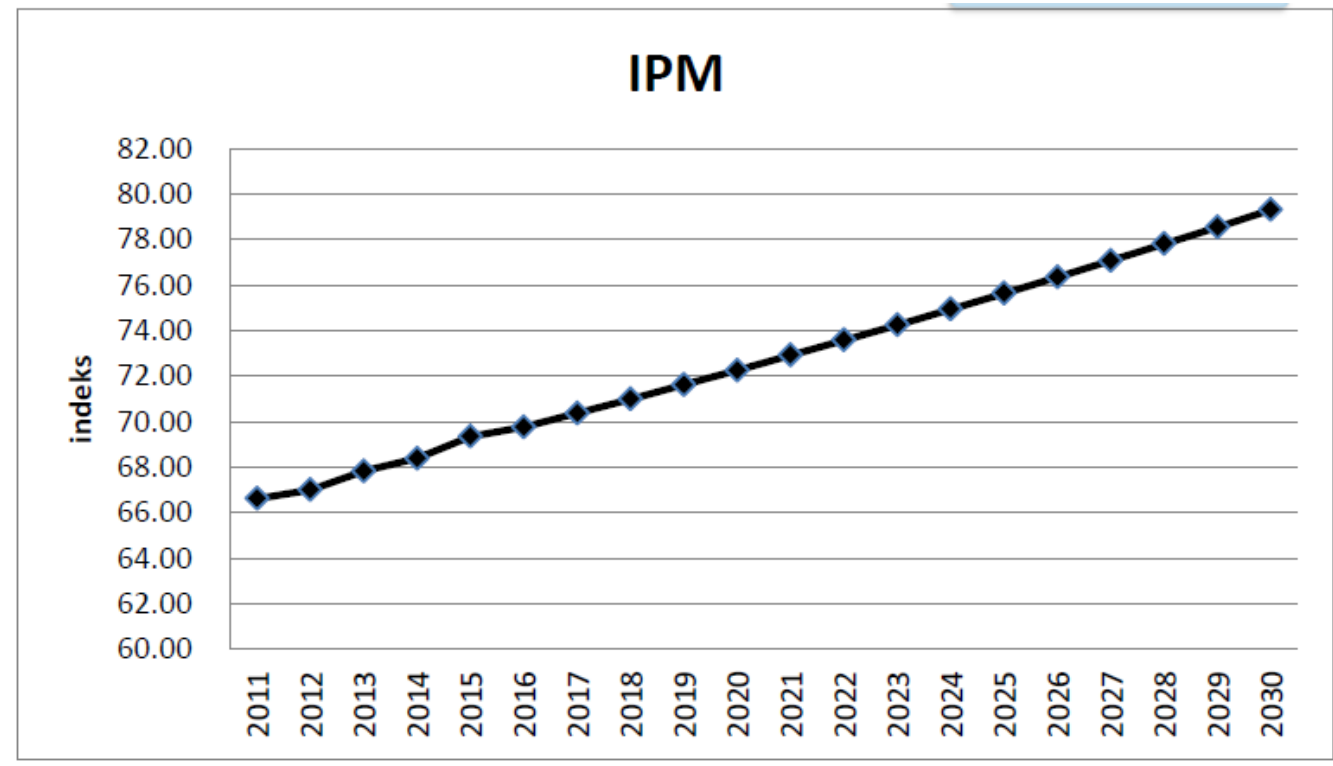

Gambar 5 IPM Jawa Tengah hasil simulasi tahun 2011-2030

Tingkat pengangguran terbuka (TPT) Jawa Tengah dalam kurun waktu 2011- 2030 mengalami penurunan. Kurun waktu 20112015, TPT Jawa Tengah mengalami perkembangan yang fluktuatif, namun pada tahun berikutnya hingga tahun 2030 terus mengalami penurunan. Pada tahun
2030, TPT Jawa Tengah sebesar 1.92 persen (Gambar 6). Penurunan tingkat pengangguran terbuka di Jawa Tengah dipicu oleh kenaikan penyerapan tenaga kerja sektoral yang lebih besar dibandingkan dengan peningkatan jumlah penduduk angkatan kerja. 


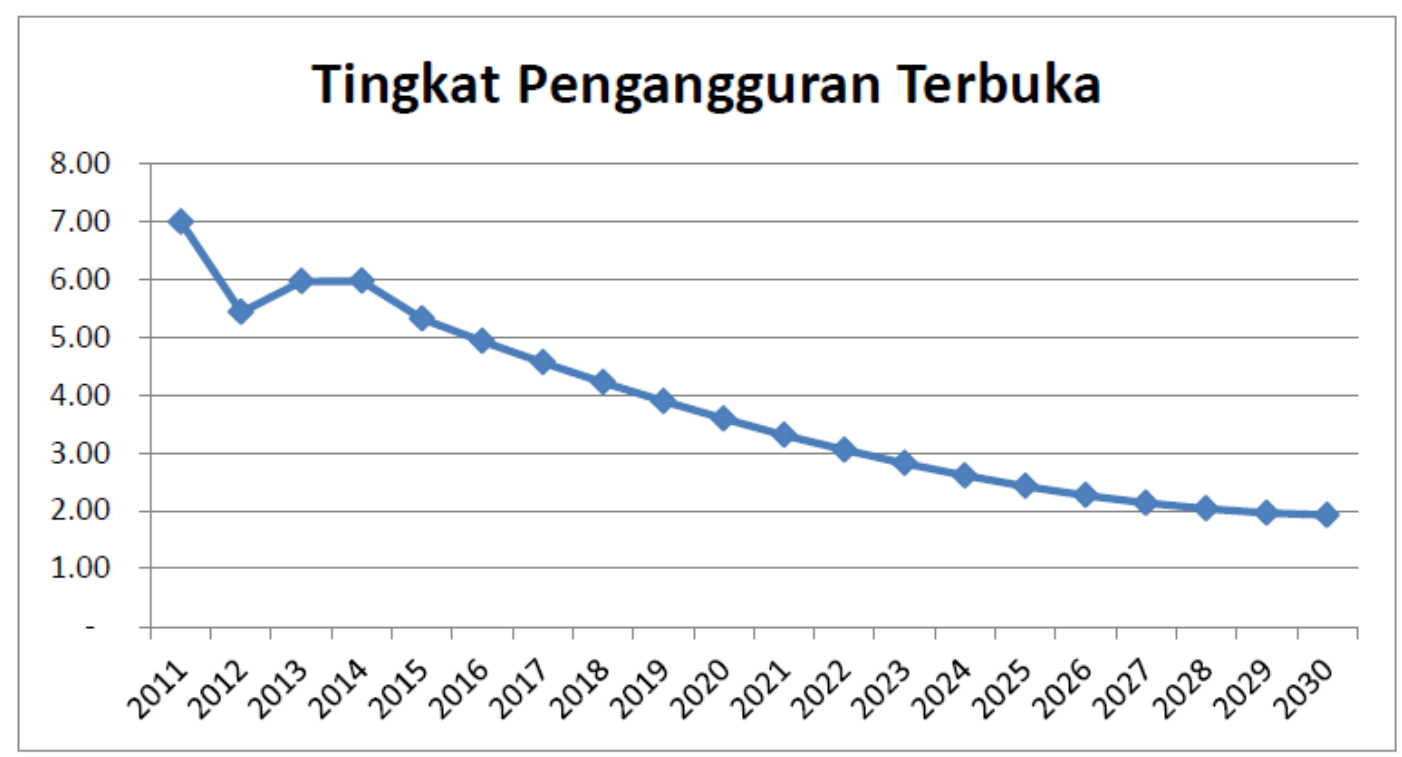

Gambar 6 Tingkat pengangguran terbuka Jawa Tengah tahun 2011-2030 hasil simulasi

Peningkatan PDRB dan IPM serta penurunan tingkat pengangguran memberikan dampak signifikan terhadap angka kemiskinan di Jawa Tengah (Gambar 7). Sejalan dengan hal tersebut, Puspita (2015) serta Rusdarti dan Sebayang (2013) dalam penelitiannya menyatakan bahwa variabel pengangguran atau tingkat pengangguran terbuka mempunyai pengaruh yang positif terhadap kemiskinan di Jawa Tengah. Sedangkan Fadlillah et al. (2016) menyatakan bahwa variabel tingkat pengangguran berpengaruh positif dan variabel IPM berpengaruh negatif terhadap kemiskinan di Jawa Tengah. Berdasarkan hasil simulasi, angka kemiskinan di Jawa Tengah terus mengalami penurunan dari sebesar 15.96 persen pada tahun 2011 menjadi 4.66 persen pada tahun 2030. Hal tersebut mengindikasikan terjadinya peningkatan tingkat kesejahteraan masyarakat Jawa Tengah.

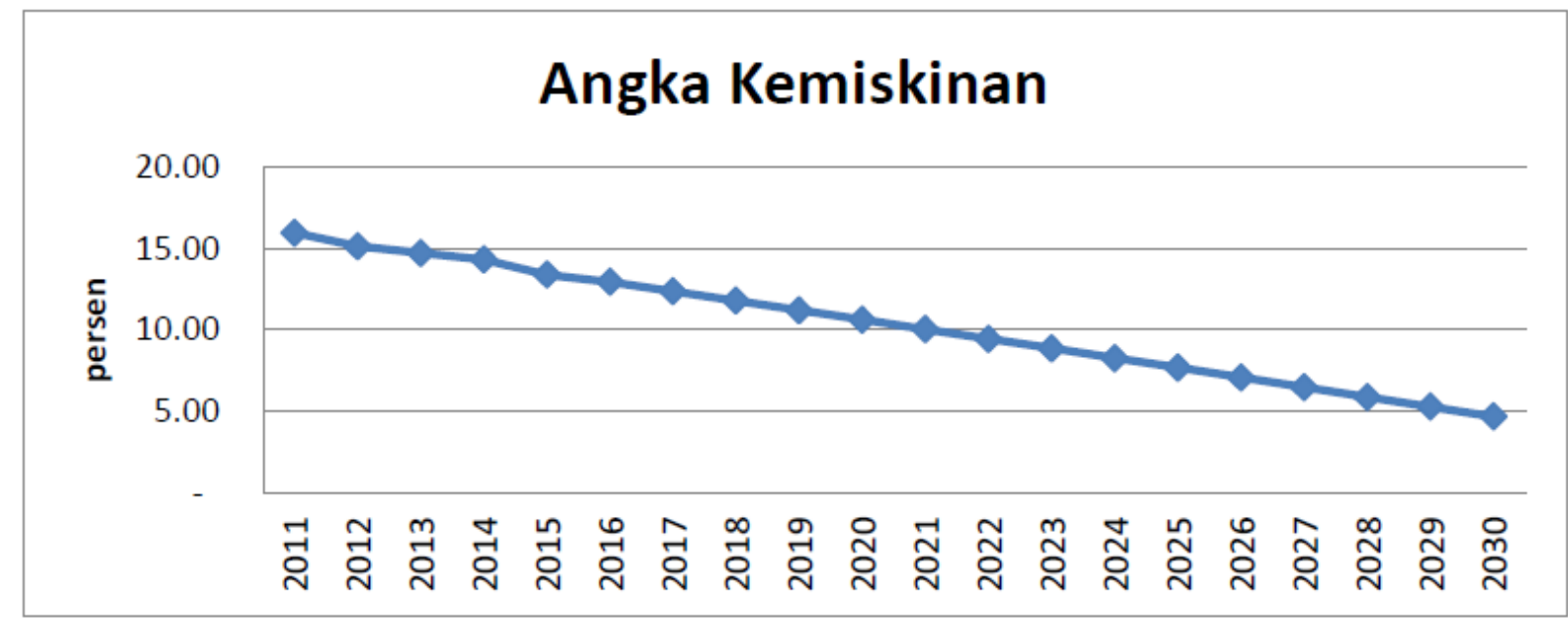

Gambar 7 Angka kemiskinan Jawa Tengah tahun 2011-2030 hasil simulasi

\section{Skenario Model}

Untuk mengetahui dampak peningkatan konsumsi pemerintah pada sektor industri makanan dan minuman, digunakan
3 skenario, yaitu :

1. Peningkatan alokasi anggaran sebesar 10 persen pada setiap periode/tahun. 
2. Peningkatan alokasi anggaran sebesar 30 persen pada setiap periode/tahun.

3. Peningkatan alokasi anggaran sebesar 50 persen pada setiap periode/tahun.

\section{Hasil Simulasi Model (Skenario)}

Dibandingkan hasil simulasi pada kondisi existing, hasil simulasi dengan menggunakan skenario 1,2 dan 3 menunjukkan bahwa terjadi peningkatan pada variabel PDRB harga konstan dan IPM serta tingkat pengangguran terbuka sedangkan angka kemiskinan mengalami penurunan (Tabel 4).

Pada skenario 1, dengan peningkatan anggaran sebesar 10 persen, PDRB Jawa Tengah tahun 2016 mengalami peningkatan sebesar 0.08 triliun rupiah menjadi sebesar 847.95 triliun rupiah, dan pada tahun 2030 mengalami peningkatan sebesar 2.59 triliun rupiah menjadi sebesar 1807.26 triliun rupiah. Tingkat Pengangguran Jawa Tengah pada kurun waktu 2016 sampai dengan 2030 naik sebesar 0.01 menjadi sebesar 4.93 persen pada tahun 2016 dan sebesar 1.94 persen pada tahun 2030. IPM Jawa Tengah tidak mengalami perubahan pada tahun 2016 namun meningkat sebesar 0.02 pada tahun 2030 menjadi sebesar 79.34. Sedangkan angka kemiskinan tidak mengalami perubahan pada tahun 2016 dan turun sebesar 0.01 persen pada tahun
2030 menjadi sebesar 4.65 persen.

Hasil skenario 2 menunjukkan bahwa dibandingkan data hasil existing, PDRB harga konstan Jawa Tengah mengalami kenaikan pada tahun 2016 sebesar 0.23 triliun rupiah menjadi sebesar 848.1 triliun rupiah, sedangkan pada tahun 2030 naik sebesar 7.78 triliun rupiah. Tingkat pengangguran naik sebesar 0.01 persen pada tahun 2016 dan naik sebesar 0.04 persen pada tahun 2030 menjadi sebesar 1.97 persen. IPM dan angka kemiskinan tidak mengalami perubahan pada tahun 2016 namun mengalami kenaikan pada tahun 2030. Pada tahun 2030, IPM naik menjadi 79.36 dan anga kemiskinan turun menjadi sebesar 4.64 persen. Pada skenario 3, dengan kenaikan alokasi anggaran sebesar 50 persen, PDRB naik sebesar 0.39 triliun rupiah pada tahun 2016 menjadi sebesar 848.26 triliun rupiah, dan meningkat sebesar 12.99 triliun menjadi sebesar 1817.66 triliun rupiah. Tingkat pengangguran naik menjadi sebesar 4.93 persen pada tahun 2016 dan mejadi sebesar 2persen pada tahun 2030. IPM tahun 2016 tidak mengalami perubahan dibanding data existing, namun meningkat sebesar 0.07 menjadi sebesar 79.39 pada tahun 2030. Sedangkan angka kemiskinan turun sebesar 0.04 persen menjadi 4.62 persen pada tahun 2030. Hasil simulasi model terhadap 3 (tiga) skenario dapat dilihat pada Tabel 4.

Tabel 4 Hasil simulasi model

\begin{tabular}{|c|c|c|c|c|c|c|c|}
\hline \multirow[b]{2}{*}{ Tahun } & \multirow[b]{2}{*}{ Existing } & \multicolumn{2}{|c|}{ Skenario 1} & \multicolumn{2}{|l|}{ Skenario 2} & \multicolumn{2}{|c|}{ Skenario 3} \\
\hline & & Nilai & $\Delta$ & Nilai & $\Delta$ & Nilai & $\Delta$ \\
\hline \multicolumn{8}{|c|}{ PDRB harga konstan (triliun rupiah) } \\
\hline 2016 & 847.87 & 847.95 & 0.08 & 848.10 & 0.23 & 848.26 & 0.39 \\
\hline 2030 & 1804.67 & 1807.26 & 2.59 & 1812.45 & 7.78 & 1817.66 & 12.99 \\
\hline \multicolumn{8}{|c|}{ TPT (\%) } \\
\hline 2016 & 4.92 & 4.93 & 0.01 & 4.93 & 0.01 & 4.93 & 0.01 \\
\hline 2030 & 1.92 & 1.94 & 0.01 & 1.97 & 0.04 & 2.00 & 0.07 \\
\hline \multicolumn{8}{|c|}{ IPM (Indeks) } \\
\hline 2016 & 69.77 & 69.77 & 0.00 & 69.77 & 0.00 & 69.77 & 0.00 \\
\hline 2030 & 79.32 & 79.34 & 0.02 & 79.36 & 0.04 & 79.39 & 0.07 \\
\hline \multicolumn{8}{|c|}{ Angka Kemiskinan (\%) } \\
\hline 2016 & 12.95 & 12.95 & 0.00 & 12.95 & 0.00 & 12.95 & 0.00 \\
\hline 2030 & 4.66 & 4.65 & -0.01 & 4.64 & -0.02 & 4.62 & -0.04 \\
\hline
\end{tabular}


Hasil dari beberapa skenario tersebut setidaknya menunjukkan bahwa semakin besar peningkatan konsumsi pemerintah pada sektor industri makanan dan minuman memberikan dampak yang semakin besar pula terhadap pembangunan ekonomi Jawa Tengah yang ditunjukkan dengan peningkatan PDRB dan IPM, serta penurunan angka kemiskinan, namun semakin besar peningkatan alokasi anggaran justru berdampak pada peningkatan tingkat pengangguran yang semakin besar pula. Berdasarkan model yang dibuat, peningkatan penyerapan tenaga kerja sebagai dampak adanya peningkatan alokasi anggaran pada sektor industri makanan dan minuman menimbulkan dampak pula terhadap peningkatan jumlah angkatan kerja di Jawa Tengah, namun jumlah peningkatan angkatan kerja lebih besar dibandingkan peningkatan penyerapan tenaga kerja, akibatnya jumlah pengangguran mengalami kenaikan.

\section{SIMPULAN}

Berdasarkan hasil penelitian dan analisis yang telah dilakukan, dapat disimpulkan sebagai berikut :

1. Sektor industri makanan dan minuman memiliki peran yang signifikan terhadap perkembangan ekonomi regional Jawa Tengah, hal tersebut ditunjukkan dengan tingginya koefisien forward linkage (2.42) dan backward linkage (2.18). Indeks forward dan backward linkage sektor industri makanan dan minuman yang lebih dari 1 menunjukkan bahwa sektor tersebut merupakan sektor kunci (key sector) di Jawa Tengah yang harus dikembangkan karena akan menimbulkan dampak multiplier yang besar terhadap pembangunan ekonomi Jawa Tengah.

2. Simulasi model terhadap peramalan kondisi PDRB harga konstan, IPM, tingkat pengangguran terbuka dan angka kemiskinan Jawa Tengah kurun waktu 2016-2030 menunjukkan bahwa terjadi peningkatan PDRB harga konstan dan IPM serta penurunan tingkat pengangguran dan kemiskinan di Jawa Tengah. Peningkatan alokasi anggaran pemerintah daerah melalui konsumsi pemerintah pada sektor industri makanan dan minuman menunjukkan bahwa semakin besar peningkatan alokasi anggaran akan memberikan dampak yang semakin besar pula terhadap peningkatan PDRB harga konstan dan IPM serta dalam menurunkan angka kemiskinan di Jawa Tengah. Namun, peningkatan alokasi anggaran tersebut justru menyebabkan tingkat pengangguran di Jawa Tengah meningkat.

\section{DAFTAR PUSTAKA}

[BPS] Badan Pusat Statistik Republik Indonesia. 2008. Kerangka Teori dan Analisis Tabel Input-Output. Jakarta (ID): Badan Pusat Statistik RI.

[BPS] Badan Pusat Statistik Republik Indonesia. 2009. Analisis Kemiskinan, Ketenagakerjaan, dan Distribusi Pendapatan. Jakarta (ID): CV Nario Sari.

[BPS] Badan Pusat Statistik Republik Indonesia. 2016a. Produk Domestik Regional Bruto ProvinsiProvinsi di Indonesia Menurut Lapangan Usaha. Jakarta (ID): Badan Pusat Statistik RI.

[BPS] Badan Pusat Statistik Republik Indonesia. 2016b. Penghitungan dan Analysis Kemiskinan Makro Indonesia 2016. Jakarta (ID): Badan Pusat Statistik RI.

[BPS] Badan Pusat Statistik Republik Indonesia. 2016c. Indeks Pembangunan Manusia 2015. Jakarta (ID): Badan Pusat Statistik RI. 
[BPS] Badan Pusat Statistik Provinsi Jawa

Tengah. 2016d. Profil

Ketenagakerjaan Jawa Tengah

Hasil Sakernas Agustus 2015.

Semarang (ID): Badan Pusat

Statistik Provinsi Jawa Tengah.

[BPS] Badan Pusat Statistik Provinsi Jawa

Tengah. 2016e. Produk Domestik

Regional Bruto Menurut Lapangan

Usaha Jawa Tengah 2011-2015.

Semarang (ID): Badan Pusat

Statistik Provinsi Jawa Tengah.

[Disperindag Prov. Jawa Tengah] Dinas

Perindustrian dan Perdagangan

Provinsi Jawa Tengah. 2014. Buku

Rekapitulasi Data Industri Agro,

Kimia dan Hasil Hutan Provinsi

Jawa Tengah 2014. Semarang (ID):

Dinas Perindustrian dan

Perdagangan Provinsi Jawa Tengah.

Fadlillah N, Sukiman, Dewi AS. 2016.

Analisis Pengaruh Pendapatan Per

Kapita, Tingkat Pengangguran,

IPM dan Pertumbuhan Penduduk

Terhadap Kemiskinan di Jawa

Tengah Tahun 2009-2013. Eko-

Regional. 11(1):18-26.

Firmansyah I. 2016. Model Pengendalian

Konversi Lahan Sawah di Dalam

DAS Citarum [disertasi]. Bogor

(ID): Institut Pertanian Bogor.

Jhingan ML. 2007. Ekonomi Pembangunan dan Perencanaan.

Jakarta (ID): RajaGrafindo

Persada.

Kuncoro M. 1997. Ekonomi

Pembangunan : Teori, Masalah

dan Kebijakan.

Yogyakarta (ID): UPP AMPYKPN.

Kuncoro M. 2007. Ekonomika Industri Indonesia. Sudiyarto $\mathrm{OH}$, editor. Yogyakarta (ID): Andi Offset.

Muhammadi, Aminullah E, Soesilo B. 2001. Analisis system Dinamis Lingkungan Hidup, Sosial, Ekonomi, Manajemen. Jakarta (ID): UMJ Press.

Nazara S. 1997. Analisis Input Output. Rahardja P, editor. Jakarta (ID): Fakultas Ekonomi Universitas Indonesia.
Nazara S. 1997. Analisis Input Output.

Rahardja P, editor. Jakarta (ID): Fakultas Ekonomi Universitas Indonesia.

[Pemprov. Jawa Tengah] Pemerintah Provinsi Jawa Tengah. 2014.

Peraturan Daerah Provinsi Jawa

Tengah Nomor 5 Tahun 2014 tentang Rencana Pembangunan Jangka Menengah Daerah (RPJMD) Provinsi Jawa Tengah Tahun 2013-2018. Semarang (ID): Pemerintah Provinsi Jawa Tengah.

Prasojo E. 2015. Model Kebijakan Pengelolaan Lingkungan Pertambangan Batubara Berkelanjutan (Studi Kasus Pertambangan Batubara di Sekitar Kota Samarinda, Kalimantan Timur) [disertasi]. Bogor (ID): Institut Pertanian Bogor.

Puspita DW. 2015. Analisis Determinan Kemiskinan di Provinsi Jawa Tengah. JEJAK.

8(1):100-107.

doi:10.15294/jejak.v8i1.3858.

Rusdarti, Sebayang LK. 2013. FaktorFaktor Yang Mempengaruhi Tingkat Kemiskinan di Provinsi Jawa Tengah. Jurnal Economia. 9(1):1-9.

Rustiadi E, Saefulhakim S, Panuiu DR. 2011. Perencanaan dan Pengembangan Wilayah. Pravitasari, AE, editor. Jakarta (ID): Crestpent Press dan Yayasan Pustaka Obor Indonesia.

Sudarmono M. 2006. Analisis Transformasi Struktural, Pertumbuhan Ekonomi dan Ketimpangan Antar Daerah di Wilayah Pembangunan I Jateng [tesis]. Semarang (ID): Universitas Diponegoro.

Sukirno S. 2006. Ekonomi Pembangunan - Proses, Masalah dan Dasar Kebijakan.

Jakarta (ID): Kencana.

Tarigan R. 2005. Ekonomi Regional Teori dan Aplikasi Edisi Revisi. Jakarta (ID): Bumi Aksara. 